more notable for the extent to which she is willing to accommodate cultural demands. Thus, she keeps on the agenda all of the cases she considers, including sati. However, her purpose is neither to endorse these cultural practices, nor to come up with right answers on specific issues; that would contradict the nature of her project. Rather it is to propose an arrangement in which women can participate on genuinely equal terms with men in determining their own future, including what they should embrace and discard in their inherited cultures.

Does Mookherjee succeed in squaring the circle? Inevitably some will find her too ready to appease the demands of conservative religious and cultural groups; others will find her too willing to subordinate the claims of culture to liberally inspired principles of freedom and equality. Mookherjee herself accepts that we sometimes have to settle for balances and compromises in a world in which 'human values cannot be perfectly reconciled', and that the choices she seeks to secure for women will not always be easy choices for them. But, for the most part, her claim is that, if we conceive the issue women's rights and cultural diversity as one of conflict, we have already set out on the wrong path. It is for women, in their full cultural particularity, to speak for themselves.

Mookherjee's book is rich in argument and empirical detail and every sentence is clearly the product of careful reflection. She packs an awful lot into each paragraph. Because she is so alive to the multitude of considerations that bear on the issues she examines, argument and counter-argument follow one another in quick succession, giving the reader little chance to relax. Her book is also impressively erudite; there seems nothing of relevance to her subject that Mookherjee has not read. Hers will not be the last word on this contentious subject, but her thoughtful, original and carefully crafted argument constitutes a major contribution to the debate and one that deserves to be widely read.

Peter Jones

Newcastle University, UK

\title{
The political art of Bob Dylan
}

David Boucher and Gary Browning (eds.)

Imprint Academic, Exeter, 2nd edn., 2009, 274pp., £14.99,

ISBN: 978-1845401207

Contemporary Political Theory (2012) 11, e7-e10. doi:10.1057/cpt.2010.33 
This book is, in part, a labour of love by scholars who are, in most cases, not Dylan specialists, nor music critics, nor literary, nor cultural studies specialists. They are all Dylan enthusiasts. Most are senior political scientists. The quality of the contributions varies. The book comprises eight essays and an introduction by the co-editors (which summarises all the chapters and discusses theoretical issues). All the chapters look at Dylan's relationship to politics and to 'the political', from his earliest protest songs to the present and, more widely, his contribution to social and political thought. The chapters cover a wide range justice, injustice, alienation, the need to escape, the surreal absurdity and cruelty of power, the outlaw, and the role of politics throughout his work; a tantalising chapter on the 'Judas!' moment in 1966; on Dylan and Live Aid; Dylan and notions of self-recovery and return; and a stimulating concluding theoretical chapter (though which seems to have two titles).

At one level, Dylan's politics are easy to identify (pretty standard liberal stuff): pro-civil rights, anti-nuclear Armageddon, anti-injustice and antiestablishment. These essays are unusual for arguing that the interesting aspects of Dylan's political thought come after the overtly political songs of the 'protest song' period. His politics became more complicated and problematic as his aesthetics became more complex. Moreover, his politics shift as he struggled against what he had become, the political and cultural 'spokesperson of his generation'. Dylan generally played at all the right events (The March on Washington, The Concert for Bangladesh, Live Aid and so on) but also tried to maintain his 'original vagabond' status, and this for both poetic and political reasons. As Boucher and Browning point out in their introduction, his early status was poetic as much as political. Some of the early protest songs, such as 'The Lonesome Death of Hattie Carroll', are among the most brilliant songs he ever wrote. And the 'transition', his 'social expressionist', period (circa 1963-1965), as Wilde points out, saw with songs like 'Chimes of Freedom' and 'My Back Pages' some of the most poetic modern songs ever written.

Disentangling his politics from his evolving aesthetics is, therefore, not an easy task. Identifying his politics as truly existing in his poetics is even more difficult. Identifying a political aesthetics, as these essays try to do, is as elusive as the artist himself. The chapters come at the problem from a range of perspectives. Adorno, social expressionism, Collingwood, Oakeshott, Lorca, and Lyotard (and some Badiou, Zizek and Lacan) are all used to capture Dylan's political art and its place, and add sophistication to the study of Dylan.

Historically, a lot of Dylan criticism had been good, and often exciting, but a lot, especially from the point of view of aesthetics, terrible. By looking at both his social significance and his aesthetic significance, the authors, and particularly the co-editors in their discussions, offer a possible conflation of the two. Dylan's political art is about freedom and about being revolutionary in 
art. The political and social implications of Dylan's evolution are accentuated when he moves from what Boucher calls his being a craftsmen, to the breathtaking explosion of creativity in his monumental trio of albums, Bringing It All Back Home, Highway 61, and Blonde on Blonde. As the co-editors point out, this was his most 'hedonistic' phase, and yet the moment when he became a poetical and philosophical exemplar for millions of people. These three albums were, artistically and culturally, paradigm shifting; and in them the 'poet', this poet, became the expression of a collective, generational and international Zeitgeist. His love songs, ironically and especially, are revolutionary in that sense - 'Love Minus Zero', 'I Want You' and so on, redefined the love song, recast how love might be expressed - although their (inevitable) male-centric quality warrants a chapter on Dylan and gender politics, absent from this collection.

If Dylan is most universal when apparently most personal, he is perhaps most authoritarian when overtly political. Angry and authoritarian in some of the 'protest' songs, the narrator (we shall come back to this) draws his righteousness from an Old Testament fury. Many of these songs - and here is perhaps one of the reasons for his own change in the early 1960s - are about retribution; but what we all really want - and him especially - is New Testament redemption. Ironically, the Old Testament element of Dylan's cruel righteousness returned with a vengeance in the late 1970s when he became a Christian. But from the early work through the transition period in the early 1960s, then the creative explosion, then withdrawal, then through the 'Christian' moment, to the return to a more secular voice, and endless tours, Dylan became a compelling expression of the dilemma of the artist's relation to the social, cultural and political (and psychological) springs of commitment to anything (and to everything). The artist, by definition hypersensitive to culture (for better or worse), always has to deal somehow with the ethical framework informing society. High and mighty traps exist in all areas of human enquiry and artistic expression, and Dylan's work is a thrilling expression of the dilemmas these create.

There are two things partly missing from this interesting book; the first understandably so, the second heuristically problematic. The first: Dylan is, as he is sometimes introduced these days, the poet laureate of rock; but he has also produced some very poor stuff (the sententious, juvenile chorus to the brilliant verses of 'Hattie Caroll' are an example). Some of Dylan's work is excruciatingly bad. He tapped into the collective culture; he also sometimes tapped into the collective dross. A rounded study of Dylan's aesthetics should consider this, and the possible reasons for it. The second point is that a crucial aspect of 'literary' criticism is the distinction between author and narrator, between authorship and voice. This is, moreover, refracted again in performance arts, particularly one where the performer is a megastar. But even at the level of 
the song itself, rather than of the singer or the singing, the narrator is not the author. The voice of the poem is not the poet. When Dylan himself truly grasped this (circa 1964), his songs became timeless. The co-editors and the chapters by Jones and by Brake address this issue to a certain extent, but this is a significant weakness in many studies of Dylan; and this volume would have had greater critical academic traction if it had addressed this more fundamentally. This book is, nevertheless, a welcome contribution to the appraisal of Dylan's 'political art'.

\section{Jacques Rancière: History, politics, aesthetics}

Gabriel Rockhill and Philip Watts (eds.)

Duke University Press, Durham \& London, 2009, viii + 358pp., Paperback $£ 16.99$, Hardback £56.99, ISBN: 978-0822345060

Contemporary Political Theory (2012) 11, e10-e13. doi:10.1057/cpt.2010.41

In his contribution to this excellent edited volume, Alain Badiou situates the development of Jacques Rancière's thought in the intellectual milieu of 1960s France. The defining issue that had emerged in this context concerned the relation between intellectual authority and social action, that is, the problem of transmission of revolutionary experience. Badiou outlines how Rancière has engaged in a 'struggle on two fronts' in developing a response to this problem (41).

On one front, Rancière has struggled against a 'scientific position that fetishized concepts' (31). This was the basis of Ranciere's break with Althusser and the idea that social movements depend on intellectuals and the party to understand how to be emancipated. On this view, as Rancière puts it, the oppressed 'are where they are because they don't know where they are. And they don't know why they are where they are because they are where they are' (275). The role of the intellectual is to enlighten, through teaching, the masses what they do not know. In contrast, Rancière's concern is to understand the forms of knowledge produced by social movements that seek to 'reframe common sense' (277).

On the other front, Rancière has struggled against a 'praxical position that fetishized action and the immediate ideas of its agents' (31). Here, 